11. Libina A. V. Sovladajushhij intellekt: chelovek v slozhnoj zhiznennoj situacii. M.: Jeksmo, 2008. $400 \mathrm{~s}$

12. Prakticheskaja psihodiagnostika. Metodiki i testy: uchebnoe posobie / red.sost. D. Ja. Rajgorodskij. Samara: Izdatel'skij Dom "BAHRAH", 2012. 672 s.

13. Sannikova O. P., Brynza I. V. Test-oprosnik perezhivanija professional'nogo krizisa (faktornyj analiz). Visnik Harkivs'kogo universitetu. Serija Psihologija. 2000. №472. S.28-32.

14. Ul'janova T.Ju. Spivvidnoshennja zhittestijkosti ta emocijnosti osobistosti. Naukovij visnik Hersons'kogo derzhavnogo universitetu. Serija Psihologichni nauki. 2020. \#3. S.72-80.

15. Fomina N.F., Fedoseeva T.E. Issledovanie pokazatelej zhiznestojkosti $v$ aspekte lichnosti professionala. Sovremennye problemy nauki i obrazovanija. - 2016. - \# 6.; URL: http://www.scienceeducation.ru/ru/article/view?id=25947.

16. Fominova A.N. Zhiznestojkost' lichnosti: monografija. Moskva MPGU, Prometej, 2012. $152 \mathrm{~s}$

17. Chihancova O. Zhittestijkist' ta iii zv'jazok iz cinnostjami osobistosti. Problemi suchasnoï psihologiï. 2018. Vip. 42. S. 211-231.

18. Dymecka, J., Bidzan-Bluma, I., Bidzan, M., Borucka-Kotwica, A., Atroszko, P., Bidzan, M. Validity and reliability of the Polish adaptation of the Health-Related Hardiness Scale - the first confirmatory factor analysis results for a commonly used scale. Health Psychology Report. 2020. T. 8. Vol. 3. P. 248- 262
19. Khoshaba, D., \& Maddi, S. Early Antecedents of Hardiness. Consulting Psychology Journal, Spring 1999. Vol. 51, (n2), 1999. P. 106- 117.

20. Kowalski, CM., Schermer, J. A. Hardiness. Perseverative Cognition, Anxiety and Health-Related Outcomes: A Case for and Against Psychological Hardiness. Psychologycal Reports. 2019. T. 122. Vol. 6. P. 2096- 2118.

21. Luceno-Moreno, L., Talavera-Velasco, B Jaen-Diaz, M., MartinGarcia, J. Hardy Personality Assessment: Validating the Occupational Hardiness Questionnaire in Police Officers. Professional PsychologyResearch and Practice. 2020. T 51. Vol. 3. P. 297- 303.

22. Maddi, S. Hardiness: An operationalization of existential courage. Journal of Humanistic Psychology, 2004. 44, 279-298.

23. Maddi, S. The Story of Hardiness : Twenty Years of Theorizing, Research, and Practice. Consulting Psychology Journal: Pracice and Research. 2002. Vol. 54. №3. P. 173-185.

24. Malkin, V., Rogaleva, L., Kim, A., Khon, N. The Hardiness of Adolescents in Various Social Groups Frontiers in Psychology. 2019. Vol. 10.

25. Mazzetti, G., Guglielmi, D., Topa, G. Hard Enough to Manage My Emotions: How Hardiness Moderates the Relationship Between Emotional Demands and Exhaustion. Frontiers in Psychology. 2020. Vol. 11.

Надійшла до редколегії 29.08.20

Рекомендована до друку 05.10.20

Iryna Brynza, PhD (Psychological Sciences), Associate Prof.,

K.D. Ushinsky South Ukrainian National Pedagogical University, Odessa, Ukraine

Oksana Kuznetsova, PhD (Psychological Sciences), Associate Prof.

Odessa Academy of Continuing Education, Odessa, Ukraine

\title{
TEST QUESTIONNAIRE "PARTIAL POSITIONS OF PERSONALITY HARDINESS": RESULTS OF CREATION AND APPROBATION
}

The article presents the theoretical construction, stages of creation and results of psychometric verification of the test questionnaire "Partial positions of personality hardiness" (PPH). Hardiness stands for the ability of an individual to assimilate experience and development during life's difficulties. Partial positions of personality hardiness cover a specific manifestation of the characteristics in different types of hardships, which is implemented in a range of emotional reactions and feelings, the nature of psychological difficulties, mechanisms of assimilation of problem experience, coping strategies and transformation of unpleasant circumstances.

The developed test questionnaire contains 100 statements, distributed on 5 scales of 20 statements each: "hardiness in a situation of stress", "hardiness in a situation of frustration", "hardiness in a situation of conflict", "hardiness in a crisis", "resilience in situations of uncertainty". The algorithm of the original method construction provided for several stages that meet the requirements of modern psychometrics. At the stage of approbation of the test questionnaire its reliability (method of division in half, parallel test, check of independence of results from the personality of the diagnostician), obvious, constructive, convergent; competitive validity (methods of correlation, factor analysis), discriminativeness has been verified. The presence of correlations between the indicators of the PPH test questionnaire and the S. Muddy Test of hardiness (adapted by D. Leontiev, O. Rasskazova) indicates that the developed method measures the same psychological quality as the reference test, but low (from 0.20 to 0.30 ) and average (from 0.30 to 0.50 ) values of correlation coefficients indicate that the new method has different theoretical construction grounds. Comparison of data between the test-questionnaire of PPH and parallel tests ("Test-questionnaire of indicators' diagnostics of psychological crisis experience" (PE) (O. Sannikova, I. Brynza), and a method of "Self-assessment of mental states according to G. Eysenck") showed existence of negative correlations between of the majority of comparative methods' indicators of $(p \leq 0.01 ; p \leq 0.05)$.

The results of approbation approved the conformity of the created method in accordance with psychometric requirements, which allows to use it both for scientific and practical purposes.

Keywords: hardiness, stress situation, frustration situation, crisis situation, conflict situation, uncertainty situation, psychometric indicators.

Bulletin of Taras Shevchenko National University of Kyiv. Series "Psychology". № 1(11), pp. 22-26 (2020) УДК 159.923

DOI: https://doi.org/10.17721/BSP.2020.1(11).4
ISSN 1728-3817

(C) Taras Shevchenko National University of Kyiv,

Publishing and Polygraphic Center "Kyiv University", 2020

\section{Юліана Букатару, канд. фармацевт. наук, асист. Вищий державний навчальний заклад України "Буковинський державний медичний університет", Чернівці, Україна \\ Марина Рева, канд. психол. наук, ст. викладач Полтавський національний педагогічний університет імені В.Г.Короленка, Полтава, Україна Ксенія Березяк, викладач \\ Львівський державний університет безпеки життєдіяльності, Навчально-науковий інститут психології та соціального захисту, Львів, Україна}

\section{ФОРМУВАННЯ ТА КЛАСИФІКАЦІЯ ПСИХОСОМАТИЧНИХ РОЗЛАДІВ}

Базовими прийнято вважати три аспекти психосоматичних дефектів: психічні розлади, які проявляються в соматичній сфері, психічні розлади, які сформувались на основі соматичної патології, соматичні розлади, що зумовлені психічними патологіями, аномаліями особистості та психогенними чинниками. Ключовими ознаками можуть бути: органічні симптоми, фізіологічні кореляти тривожності, симптоми, які проявляються під час формування та розвитку психосоматичних розладів.

Ключові слова: стрес, фармакологічна корекція, психосоматози, медична психологія, патопсихологія.

Вступ. Сучасний високотехнологічний інформаційно насичений світ зумовлює загострення проблеми зростання психологічного навантаження і стресів, що надає проблемі здоров'я та хвороби особливого значення. Психічні аномалії можуть здійснювати вплив на життя будь-якої людини не залежно від ії статусу, статку, професії. Психічні розлади можуть стати причиною тяжких страждань, які випадають на долю людини, або навпаки, стати джерелом натхнення та енергії. За рахунок того, що, на сучасному етапі, розрізняють два основних ком- 
поненти здоров'я, психічне та фрізичне, лікування хвороб різного типу відбувається по-різному, різними галузями науки. Наука яка вивчає психологічні вади та відхилення отримала назву патологічної психології.

Зважаючи на той фракт, що основу класифікації психосоматичних розладів можуть становити різні критерії, а загальної системи класифікацій не існує, актуальності набуває проблема визначення класифікацій, які $є$ найбільш популярними та використовуються для визначення різних психосоматичних розладів, а також під час визначення основних фракторів, що зумовили їх виникнення та прояв.

Мета нашої статті полягає в необхідності визначення найбільш відомих та класичних підходів до класифікації психопатологічних захворювань, а також визначення причин їх виникнення.

Психологічна психологія або патопсихологія - це наука яка вивчає, систематизує та розкриває особливості різних видів психічних хвороб, визначає засоби профрілактики даних захворювань та орієнтована на визначення методів та прийомів, які будуть максимально ефективними під час надання психічної підтримки хворим. Дослідники патологічної психології здійснюють постійний збір інформації, що дозволяє їм збирати інформацію про досліджувані явища, описувати їх та прогнозувати особливості розвитку тієї або іншої психічної хвороби. Зібрані дослідниками дані використовуються у процесі визначення психологічної патології та для надання психологічної підтримки хворому.

Огляд літератури. Відповідно до концептуальних положень сучасної інтегративної психологічної і медичної науки, що відображають структуру психосоматичних дефектів, виділено і використовується три базових аспекти психосоматичних дефектів: психічні розлади, першоджерелом яких $є$ соматичні порушення, соматичні розлади, першоджерелом яких є психічні порушення, аномалії особистості викликані дією психопатогенних чинників (Гавенко, 2015; Бамбурак, 2019; Шевчук, 2011).

В зв'язку з тим, що постійно поглиблюються знання у галузі фрізіології, психофізіології та в напрямі психічної діяльності, а вчені постійно досліджують базові аспекти психічної та фрізіологічної діяльності людського організму, здійснюється розвиток психопатологічної науки. Першопочатково, під психосоматичними розладами в клінічній практиці розуміли дисфункції органів і систем організму, під час формування яких головним негативним чинником виступають стресові фрактори: стреси, конфлікти, кризи, катастрофи і т.п. (Лиджи-Горяева, 2020).

Відповідно до визначення запропонованого Симулевичем А.Б. психосоматичні розлади - це група хворобливих станів, які виникають за рахунок взаємодії психічних і соматичних факторів та проявляються у вигляді соматизації психічних порушень та психічних розладів які проявляються як наслідок соматичних відхилень (Ніконенко, 2016).

В статті Сєдих К.В. зазначено, що психосоматичні захворювання - це захворювання головною причиною яких $є$ психічні процеси хворого зумовлені проявом таких емоційних станів як гнів, тривога, депресія, почуття провини і т.п. (Сєдих, 2017).

У сучасній медицині поняття "психосоматичні захворювання" розглядається як група хворобливих станів, які проявляються у формі езацербації соматичної патології, формуванні загальних, що виникають під час взаємодії соматичних і психічних порушень, що відображають реакцію на психічне захворювання (Перетятько, 2017).

Не дивлячись на те, що поняття "психосоматичні захворювання" або "психосоматичні розлади" має чимало трактувань та синонімічних назв запропонованих різни- ми вченими, існує уніфріковане означення, здійснене у системі DSM. Так з того моменту, як було введено американську систему класифікації DSM-III, психосоматичні захворювання почали називати "соматоформними розладами". Разом із визначеними поняттями, у медицині використовують "функціональні соматичні порушення" (М. Перре, 2012).

Визначаючи природу психосоматичних розладів Ф. Александер робить припущення про вплив трьох основних чинників: особистісної диспозиції, конструкції (схильності органа до захворювання - конституціональний фактор) та життєва ситуація, яка виконує роль фактора, що активізує та каталізує несвідомий конфлікт. Замикаючи в собі такі емоції як почуття провини, власної неповноцінності, невиражені сексуальні імпульси та інші негативні емоції людина сама провокує подальше порушення фрункцій вегетативних органів.

Теорія Шура пояснює причини які є базовими у разі виникнення психосоматичних розладів у дітей різного віку. Автор теорії зазначає, що діти різного віку по різному реагують на психотравматичні впливи, причому, чим менше вік дитини, тим частіше ії̈ реакції мають соматичну спрямованість, але разом із тим, автор звертає увагу і на явище психосоматичної регресії (ресоматизації), яка зумовлює повернення на більш ранній тип реагування на негативні подразники.

Досліджуючи особливості формування та розвитку психосоматичних розладів актуальності набуває питання їх виникнення. Висновки таких дослідників як Волошко Н. І., Седих К. В., Перетятько Л. Г. та інших сходяться в тому, що негативні емоції $€$ одним із ключових факторів, що лежать в основі формування та розвитку психосоматичних розладів (Влошко, 2015, Седих, 2017, Перетятько, 2017). Відповідно до висновків, зроблених Седих К. В. емоції здійснюють вплив на:

- імунну систему

- гормональний баланс;

- перифреричну фрізіологічну активність (частоту серцебиття, артеріальний тиск).

Визначаючи, як емоції впивають на фізіологічний стан людини, М. Перре досліджував впив гніву, зокрема на серцево-судинну систему. Так він дійшов висновку, що гнів призводить до есенціальної гіпертонії (підвищеного кров'яного тиску), яка надалі сприяє розвитку стенокардії, інфаркту міокарда (М. Перре, 2012).

Під час проведення досліджень на щурах Г. Сельє здійснював на них вплив, зумовлюючи постійну дію стресових факторів. На основі своїх досліджень він дійшов висновку, що стрес зумовлює розвиток виразкових хвороб та порушень у роботі ендокринної системи.

В. Кенон описуючи фізіологію емоцій, відмічає, що під впливом емоцій рівень цукру в крові зростає, підвищується частота серцевих скорочень та артеріальний тиск, що доводить прямий вплив емоцій людини із роботою її соматичних систем (М.Перре,2012).

Психопатологія визначає основні причини формування та прояву психосоматичних розладів та об'єднує їх у три основних групи:

- спадкові;

- психосоціальні;

- церебрально-органічні.

Класичними психосоматичними захворюваннями вважають хвороби, психологічні фактори в етіопатогенезі яких є доведеною:

1) есенціальна гіпертензія;

2) виразкова хвороба 12-палої кишки та виразковий коліт;

3) бронхіальна астма;

4) цукровий діабет; 
5) нейродерміти;

6) ревматоїдний артрит;

7) ендокринні порушення (гіпер- та гіпотиреоз).

Близькими за ознаками прийняти вважати такі хвороби як ішемічна хвороба серця, міома матки та інші (Волошко, 2009; Кулаков, 2003).

На сьогоднішній день не існує загальної класифрікації психосоматичних розладів, тож розглянемо найбільш відомі.

Однією з перших спроб класифрікації психоневрологічних розладів $€$ класифрікація, запропонована К. Ясперсом, яка основана на визначенні ключових психосоматичних аспектів.

Першим аспектом К. Ясперс визначив соматичні відчуття, які проявляються у кожної людини в процесі життя. Автор класифікації зазначає, що відчуття, які виникають, $є$ недиференційованими та низько усвідомленими, але разом із тим, він веде мову і про патологічні відхилення, такі як: психогенна анестезія, симптоми істерії, галюцинації та псевдогалюцинації, біль, що не має органічної основи.

Другим аспектом було визначено перманентні, що супроводжують будь-яку психічну активність соматичні явища (фрізіологічний вияв емоцій)

Третій аспект - соматичні хвороби, які на пряму пов'язані із рівнем психічної активності людини. Сере них визначають такі види як:

- напади та непритомність (напади психогенного характеру, які проявляються в результаті надмірного психічного збудження);

- функціональні дисонанси в роботі внутрішніх органів (зміни голосу, слуху, фрізіологічних процесів, збої в роботі кровоносної системи, травної, а також прояв псевдоневрологічних симптомів - тремору, заїкання тощо);

- соматичні хвороби, які К. Ясперс визначає як реакцію "душі", за рахунок того, що "душа" обирає і впливає на найслабші органи, наприклад, бронхіальна астма, гастрит, виразкова хвороба, тощо;

- дефекти комплексних інстинктивних поведінкововчинкових паттернів (дисфункції сексуальні, різкі зміни у вазі, ендокринні порушення тощо).

Саме запропонована К. Ясперсом класифікація психоневрологічних розладів стала базовою і дозволила іншим застосовувати інші прийоми під час систематизації знань про види психічних розладів, за рахунок того, що саме К. Ясперс врахував всі можливі вияви емоцій та функціональних неврозів внутрішніх органів (Ясперс, 1997).

Класифікація, яка була здійснена Р. Лемке на основі такого критерію як соматоперцептивної конституції, яка властива будь-якому типу особистості. Порушення соматопсихічної сфрери об'єднують у чотири основних групи:

- невропатії (невропатична конституція), що характеризується гіперсенестезією у сфері тілесної перцепції гіперпатії, алгії, псевдомігрені, вродженої неповноцінності вегетативних функцій (судинні кризи, запаморочення, ортостатична непритомність, порушення серцебиття, пітливість тощо);гіпостенії (спричинені підвищеною втомлюваністю);

- соматотонія - гіпертрофоване усвідомлення соматичного Я з гедоністичним відчуттям підвищеного тілесного тонусу, потребою у фрізичній активності і толерантністю до надвисоких навантажень;

- пропріоцептивний діатез - парадоксальність тілесної перцепції, тобто дещо інші багатосистемні соматизовані та соматоформні порушення (альтернативні полісистемні соматизовані та/або соматоформні розлади (тілесні фан- тазії, синестезії, синестоалгіi) поєднуються з гіперстезією загального почуття тіла (Старшенбаум, 2014)

Дослідження Маркова Ю. та Беріоса Дж. дозволили виокремити деперсоналізацію, як прояв дифіцитарного усвідомленого тілесного Я з нівелюванням проблем фрізичного здоров'я, яка виражається у здатності долати тілесні недуги власними силами і сприйняттям захворювань, які можуть становити загрозу життю, раціонально, без емоційних виявів (Шаніна, 2013; Васюк Ю.А., Довженко Т.В. \& Школьник, 2009)

Результати. На основі проведеного аналізу літератури із проблеми дослідження, можемо визначити та обґрунтувати наступні патології соматопсихічної сфери:

1. Невротичні патології, які проявляються в соматичній сорері і не мають медичного обґрунтування, але містять конверсійні, соматизовані і соматоформні порушення, які вимагають прояву надмірної уваги з боку медиків.

2. Дисоціативні або конверсійні розлади, які проявляються сумісно з тілесно-патологічними відчуттями, серед яких можуть бути гіпертензії окремих ділянок шкіри, або функціональні порушення в напрямі довільної іннервації, яка зумовлює прояв порушень у моториці та координації, наприклад, психогенна афонія, парез, параліч тощо. Дисоціативні розлади, за звичай, характеризуються перебільшеною виразністю, проявів клінічних ознак та феноменів, основною причиною яких $\epsilon$ стреси 3 короткочасними виявами, з часто повторюваними реакціями.

3. Соматизований розлад, який характеризується наявністю поліморфних, мінливих тілесних відчуттів, що має назву синдрому множинних скарг: психалгії, тахікардія, психогенний кашель, дискінезії жовчних шляхів тощо. Клінічні ознаки захворювань даної групи найчастіше пов'язані із психогенними чинниками, їх тривалість сягає 4-6 місяців.

4. Соматоморфні розлади, хронічні соматоморфні болючі дефекти, що проявляються у вигляді ідіопатичні алгії що супроводжується коморбідністю з розладами тривожного і депресивного спектру, формуванням залежності від алкоголю, опіатів. 3 погляду психопатології, розлади даної групи мають вигляд обмеженої іпохондрії, як стійкої мономорфної алгії з обмеженою проекцією топографії та больовим супроводом, що зумовлює зміну поведінки та процесів мислення, які суцільно захоплені больовими відчуттями. Крім того, на поведінку особистості можуть впливати фобії іпохондричного характеру, вегетативні симптомокомплекси, можливі тактильні галюцинації як ускладнення у процесі розвитку хвороби (Carmody T. Р., 1997)

5. Аутодеструктивна поведінка із спрямуванням до елімінації пошкодженої області (само пошкодження, хірургічне втручання). Клінічні ознаки, у більшості випадків, $€$ спонтанними, зумовлені дією негативних соматогенних або психогенних чинників. Тривалість захворювань даної групи від пів року до кількох років, і, як правило, завершується повною редукцією алгічного синдрому.

6. Маскована депресія (соматизована, прихована, ларвірована, алекситемічна), або ії прояв у легкій формі у вигляді депресивного стану, циклотимії, дистимії. Основні ознаки даної групи захворювань - туга та пригніченість загального стану. Як правило хвороба може "маскуватись" і залежно від "соматичної маски" виділяють органоневротичні, гіперсомічні і гіперректичні, алогічні, депресивно-больові патологічні прояви, які стають причиною виражених імплікованих психопатологічносоматичних вад, що зумовлюють трансформацію тіла, спричиняючи неврози внутрішніх органів та соматомо- 
рфну дисфункцію вегетативної нервової системи (Бурлачук, Грабская, \& Кочарян, 2001)

7. Неврози органів, як фобічно-тривожні дефекти із комплексом симптомів вегетативного походження, що активізують морфологічні субклінічні відхилення: кардіоневроз, кардіоспазм, синдром гіпервентиляції, синдром роздратованого кишечника, порушення в будові та функціонуванні шлунка, сечового міхура тощо. Неврози органів можуть повторюватись, бути більш вираженими або прихованими але однозначно матимуть соматичну природу (Николаева,2009; Васюк, Довженко \&Школьник, 2009)

8. Кардіоневроз, що проявляється у вигляді вегетативних дисфункцій (больові відчуття, частота серцевих скорочень, підвищення артеріального тиску, загострення симптомів вегетативного характеру, втрата свідомості, запаморочення тощо), які визначаються як панічні напади, що супроводжуються фобіями, серед яких інсульто-, кардіо- та танатофобія та інші.

9. Гіпервентиляційний синдром, клінічними проявами якого $€$ напади нестачі повітря, зміни, які, у результаті, спричиняють порушення частоти дихання, аерофрагії, задишки, також можуть проявлятись панічні атаки, напади тривоги та кардіоневрози.

10. Функціональні зміни, що впливають на роботу травної системи, зокрема дисфагія та спазмами стравоходу, болі в шлунку, нудота, блювання, печія тощо), синдром роздратованого кишківника, що супроводжується діареєю, запорами, больовими відчуттями, що можуть переплітатись із загальними розладами спричиненими тривожнимим розладами та канцерофобією.

11. Неврози сечового міхура, зумовлені відчуттям страху та нетриманням сечі, феноменом агорафобії та іншими фобіями.

12. Соматоморфний свербіж, первинним проявом якого $є$ комплекс соматовегетативних симптомів, серед яких висипи на певних ділянках шкіри, еритеми, гіпертермії тощо, та вторинними виявами побічно-тривожних дефектів, які проявляються хвилями.

13. Синдром хронічної втоми, який виявляється довше ніж 6 місяців, та має стійкий характер та зумовлює рецидивне повторення симптомів навіть після незначного відпочинку. Головними ознаками даного захворювання $\epsilon$ слабкість, втома, десріцит енергії, дратівливість, погіршення пам'яті та уваги. Як наслідок хвороби проявляються артралгії, міалгії, запаморочення, головні болі, підвищення температури тіла тощо (Николаева,2009; Бурлачук, Грабская, \& Кочарян,2001)

Обговорення. Використовуючи як основний критерій "психічні розлади психотичного реєстру", які проявляються в соматичній сфері, виділяємо:

- соматопсихоз - формується та проявляється за рахунок вісцеральних сенсопатій психотичного реєстру(проявляється у формі галюцинацій, франтазій соматичного характеру, фантастичних сенсопатій, алгій різного типу) і складних ургентних функціональних дефректів. Для обґрунтування дизестетичної кризи, що супроводжується вазомоторними (прискорення пульсу, підвищений артеріальний тиск), трофічними (діурез, блювота, зміна маси тіла тощо), термічними (пропасниця) порушеннями, які будуть тісно переплітатись із проявами тривоги, ажитації, загрозою власного існування та страхом смерті, припущенням і власною фантазією про те, що хвороба може бути невиліковною, або затяжність хвороби, а її симптоми можуть погано піддаватись лікуванню;

- дерматозійні марення найчастіше формуються та проявляються у літньому віці після тривалого латентно- го періоду. Головними ознаками даного захворювання $є$ тактильний галюциноз, що супроводжується анімаційним явищем. Сенсопатії проявляються комплексно, на основі ознак рухливості та предметності, під час яких виникають та проявляються больові відчуття: уколи, печіння тощо. Марення прийнято вважати симптомом вторинної групи тактильного галюцинозу, імовірний перехід до одержимості, наприклад до одержимості зараження паразитами, яка стає причиною аутоагресивної поведінки, або проявів аутоагресивної поведінки, орієнтованої на позбавлення себе від внутрішніх паразитів (використання для їх знешкодження токсичних речовин, або гострих предметів тощо);

- іпохондричні марення (параноя), які формуються та проявляються без патологій шкіри, слизових оболонок та внутрішніх органів, але проявляються симптомами соматичного ґенезу, причиною даного прояву $є$ самолікування за допомогою ургентної терапії та можливої аутодеструктивної поведінки (аномальні соматичні ознаки, галюцинації тілесного та нюхового характеру тощо);

- параноя або іпохондричні марення під час формування не характеризуються проявами патологій на шкірі, слизових оболонках або внутрішніх органів, але супроводжуються відчуттями, що страждання $€$ суто соматичного характеру, причиною чого може бути самолікування за допомогою ургентної терапії, за рахунок проявів аутодеструктивної поведінки (аномальними соматичними ознаками, нюховими або тактильними галюцинаціями тощо);

- дисморфічні марення (іпохондрія краси), характеризується як надумана фізична вада, що є неприємною для оточуючих, характеризується власною переконаністю хворого в тому, що він має патології або деформації структури тіла. Як правило, дана переконаність стає передумовою для виникнення соціофобії, яка характеризується такими проявами як приховування надуманих дефектів зовнішності (захисні реакції), повна соціальна ізоляція (уникання), пластичні операції (хірургічні втручання) та прояв ауто деструкції (Васюк, Довженко\&Школьник, 2009; Jackson, Aiken,2000)

Висновки. Узагальнюючи, можемо говорити про те, що основними передумовами формування та прояву психосоматичних розладів можуть бути як умови психосоціальної нестабільності, так і порушення в роботі основних систем органів, таких як нервова або ендокринна. Зійшлись дослідники і в тому, що ряд психосоматичних розладів може успадковуватись, але прояв їх $\epsilon$ не обов'язковим, залежно від факторів оточуючого середовища, в яких перебуває особистість.

Щодо класифікації психосоматичних розладів, то єдиної системи класифікацій не існує, але залежно від того, який критерій взято за основу класифікації, найбільш повними можна вважати класифікацію запропоновану К. Ясперсом, Р. Лемке та інших. Узагальнивши критерії класифікації, взяті за онову Шаніною Г. Е., Васюком Ю. А., Довженко Т. В., Бурлачук Л. Ф. запропонували сучасний підхід до систематизації психопатологій, використання яких буде актуальним як у медичній психології, так і в патопсихології.

\section{Список використаних джерел}

1. Бамбурак Н. Психологічний аналіз проблеми систематики соматичних розладів // Збірник наукових праць Національної академії державної прикордонної служби України. Серія: психологічні науки - 2019 №3(14). - С. 18-31

2. Бурлачук Л. Ф., Грабская И. А., Кочарян А. С. Основы психотерапии : учебное пособие для студентов, которые обучаются по специальности "Психология". - Киев : Ника-центр, 2001. - 320 с

3. Васюк Ю. А., Довженко Т. В., Школьник Е. Л. Депрессивные и тревожные расстройства в кардиологии. - Москва, 2009. - 199 с. 
4. Волошко Н.І. Психологічні особливості внутрішньоособистісних конфліктів у хворих на артеріальну гіпертензію : монографрія / Н.І. Волошко. К. : Наук. світ, 2009. - 198 с.

5. Волошко Н.І. Психосоматичні хвороби як результат впливу негативних психологічних ффакторів // Збірник наукових праць К-ПНУ імені Івана Огієнка, Інституту психології імені ГС.Костюка НАПН України. Проблеми сучасної психології. - 2015 - № 30. - С. 126-135.

6. Клиническая психология и психотерапия / под ред. М. Перре, У. Бауманна. - [3-е изд.]. - СПб. : Питер, 2012. - 944 с.

7. Кулаков С.А. Основы психосоматики / С.А. Кулаков. - СПб. : Речь, 2003. -288

8. Лиджи-Горяева А. А. Классификация психосоматических расстройств // Инновационная наука. - 2020. - №1. - С. 116-119.

9. Мартинюк А.І. Патопсихологія. Навч. посіб. - К.: Центр навчальної літератури, 2019 - 208 с.

10. Ніконенко Ю.П. Клінічна психологія. Навч. посіб. - К.: КНТ, 2016. $369 \mathrm{c}$.

11. Перетятько Л.Г., Тесленко М.М. Психосоматичні розлади: сучасний стан проблеми // Психологія і особистість. - 2017. - №2(12). - С. 137-147.

12. Психіатрія і наркологія : підручник / В.Л. Гавенко, В.С. Бітенський, В.А. Абрамов та ін. ; за ред. В.Л. Гавенка, В.С. Бітенського. - 2-ге вид., переробл. і допов. - К. : ВСВ "Медицина" - 2015. - 512 с.

13. Психосоматика. Телесность и культура / под ред. В. В. Николаевой. - Москва : Академический проект, 2009. - 311 с.

14. Седих К.В. Формування психосоматичної компетентності в психологічному консультуванні подружніх пар // Психологія і особистість 2017. - № 2 (12). - С. 158-167.

15. Старшенбаум Г. В. Психосоматика и психотерапия. Исцеление души и тела. - Москва : Феникс, 2014. - 350 с.

16. Шанина Г. Е. Психогигиена и психопрофилактика. - Москва : Логос, 2013. $-148 \mathrm{c}$.

17. Шевчук А.М. Психосоматичні порушення у постраждалого населення внаслідок надзвичайної ситуації // Проблеми екстремальної та кризової психології. - 2011. - №10. - С. 302-313

18. Ясперс К. Общая психопатология / пер. с нем. - Москва, 1997. $1054 \mathrm{c}$

19. Carmody T. P. Health-related behaviours: common factors Cambridge Handbook of Psychology. Health and Medicine. Cambridge, 1997. P. $117-120$

20. Carver C., Harris S. How important is the perception of personal control? Personality and Social Psychology Bulletin. 2000. Vol. 26. № 2. P. 139-150.

21. Jackson K. M., Aiken L. S. A Psychosocial model of sun protection and sunbathing in young women: the impact of health beliefs, attitudes, norms, and selfefficacy for sun protection. Health Psychology. 2000. Vol. 19. № 5. P. 458-468.

\section{Referenses}

1. Bamburak N.(2019) Psyxolohichnyj analiz problemy systematyky somatychnyx rozladiv. Zbirnyk naukovyx prac" Nacional"noyi akademiyi derzhavnoyi prykordonnoyi sluzhby Ukrayiny. Seriya: psyxolohichni nauky, №3(14),s.18-31
2. Burlachuk L. F., Grabskaja I. A., Kocharjan A. S.,(2001) Osnovy psihoterapii: uchebnoe posobie dlja studentov, kotorye obuchajutsja po special'nosti "Psihologija". Nika-centr, Kiev, Ukraina.

3. Vasjuk Ju. A., Dovzhenko T. V., Shkol'nik E. L.,(2009) Depressivnye i trevozhnye rasstrojstva v kardiologii. Moskva, Rossija.

4. Voloshko N.I., (2009), Psyxolohichni osoblyvosti vnutrishn"oosobystisnyx konfliktiv u xvoryx na arterial"nu hipertenziyu : monohrafiya. Nauk. Svit, Kiev, Ukraina.

5. Voloshko N.I., (2015), Psyxosomatychni xvoroby yak rezultat vplyvu nehatyvnyx psyxolohichnyx faktoriv. Zbirnyk naukovyx prac" K-PNU imen Ivana Ohiyenka, Instytutu psyxolohiyi imeni H.S.Kostyuka NAPN Ukrayiny. Problemy suchasnoyi psyxolohiyi,№ 30, s.126-135.

6. Perre M., Baumann U., (2012), Klinicheskaja psihologija i psihoterapija,SPb.: Piter, Rossija.

7. Kulakov S.A., (2003), Osnovy psihosomatiki. SPb.: Rech, Rossija

8. Lidzhi-Gorjaeva A.A., (2020), Klassifikacija psihosomaticheskih rasstrojstv. Innovacionnaja nauka, №1, s.116-119

9. Martynyuk A.I., (2019) Patopsyxolohiya. Navchalnyj posibnyk. Centr navchalnoyi literatury, Kiev, Ukraina.

10. Nikonenko Yu.P., (2016). Klinichna psyxolohiya. Navchalnyj posibnyk. KNT, Kyyiv, Ukraina

11. Peretyatko L.H., Teslenko M.M. (2017), Psyxosomatychni rozlady: suchasnyj stan problemy. Psyxolohiya i osobystist", №2(12), s.137 - 147

12. Havenko V.L., Bitenskyj V.S., Abramov V.A. ta in. (2015), Psyxiatriya i narkolohiya: pidruchnyk - 2-he vyd., pererobl. i dopov. VSV "Medycyna", Kyyiv, Ukraina.

13. Nikolaeva V. V.(2009), Psihosomatika. Telesnost' i kultura. Akademicheskij proekt, Moskva, Rossija.

14. Sedyx K.V., (2017), Formuvannya psyxosomatychnoyi kompetentnosti $\mathrm{v}$ psyxolohichnomu konsul"tuvanni podruzhnix par. Psyxolohiya i osobystist, № 2 (12), s.158-167

15. Starshenbaum G. V., (2014), Psihosomatika i psihoterapija. Iscelenie dushi i tela. Feniks, Moskva, Rossija.

16. Shanina G. E., (2013), Psihogigiena i psihoprofilaktika. Logos, Moskva, Rossija.

17. Shevchuk A.M., (2011), Psyxosomatychni porushennya u postrazhdaloho naselennya vnaslidok nadzvychajnoyi sytuaciyi. Problemy ekstremalnoyi ta kryzovoyi psyxolohiyi, №10, s.302-313

18. Jaspers K. (1977). Obshhaja psihopatologija (per. s nem.), Moskva, Rossija.

19. Carmody T. P. Health-related behaviours: common factors Cambridge Handbook of Psychology. Health and Medicine. Cambridge, 1997. P. $117-120$

20. Carver C., Harris S. How important is the perception of personal control? Personality and Social Psychology Bulletin. 2000. Vol. 26. № 2. P. $139-150$.

21. Jackson K. M., Aiken L. S. A Psychosocial model of sun protection and sunbathing in young women: the impact of health beliefs, attitudes, norms, and selfefficacy for sun protection. Health Psychology. 2000. Vol. 19. № 5. P. 458-468

Надійшла до редколегії 14.09.20 Рекомендована до друку 15.10.20

Yuliana Bukataru, PhD in Pharmacy, Assist.

Higher State Educational Institution of Ukraine

"Bukovynian State Medical University", Chernivtsi, Ukraine

Marina Reva, PhD (Psychological Sciences), Senior Lecture

Poltava National Pedagogical University named after VG Korolenko, Poltava, Ukraine

Ksenia Berezyak, Lecturer

Lviv State University of Life Safety,

Educational and Scientific Institute of Psychology and Social Protection, Lviv, Ukraine

\section{FORMATION AND CLASSIFICATION OF PSYCHOSOMATIC DISORDERS}

According to the conceptual provisions of modern integrative psychological medical science, which highlight the features of the classification of psychosomatic disorders, the basic is considered to be three aspects of psychosomatic defects: mental disorders manifested in the somatic sphere, mental disorders formed on the basis of somatic pathology, somatic disorders pathologies, personality anomalies and psychogenic factors. In summary, we can say that the main prerequisites for the formation and manifestation of psychosomatic disorders can be both conditions of psychosocial instability and disorders of major organ systems, such as nervous or endocrine. Researchers also agree that a number of psychosomatic disorders can be inherited, but their manifestation is not mandatory, depending on the environmental factors in which the individual is. Regarding the classification of psychosomatic disorders, there is no single system of classifications, but depending on which criterion is taken as the basis of classification, the most complete can be considered the classification proposed by K. Jaspers, R. Lemke and others.

The basis for the classification of psychopathological disorders are signs that are defined as criteria. So the key signs can be: organic symptoms, physiological correlates of anxiety, symptoms that appear during the formation and development of psychosomatic disorders.

Keywords: psychopathological disorders, stress, pharmacological correction, psychosomatosis, types and manifestations of psychosomatic disorders, medical psychology, pathopsychology 